\title{
Composition of native and alien invasive species in soil seed banks of five different physiognomies in Akure Forest Reserve, Ondo State, Nigeria
}

\author{
Ayomiposi Olayinka AKINKUOLIE ${ }^{1 *}$, Rafiu. Olugbenga SANNI ${ }^{1}$, \\ Augustine. O. ISICHEI ${ }^{2}$ and Samson. O. OKE ${ }^{2}$ \\ ${ }^{1}$ Department of Biology, Adeyemi College of Education, Nigeria. \\ ${ }^{2}$ Department of Botany, Obafemi Awolowo University, Ile-Ife, Osun State, Nigeria. \\ *Corresponding author; E-mail: ayokuolie@gmail.com
}

Received: 01-08-2020

Accepted: 22-01-2021

Published: 30-04-2021

\begin{abstract}
The study investigated the composition of native and alien invasive species in soil seed banks of five different vegetation physiognomies in Akure Forest Reserve Ondo State, Nigeria. This was done with a view to determining and providing an insight into the population dynamics of alien, invasive species for subsequent prediction of potential plant population of the extant population. Five distinct sites (Natural forest, Teak plantation, Taungya system, Taungya + Teak + Gmelina and Teak + Gmelina + Pinus Plantation) designated as A, B, C, D and E were selected in the Forest Reserve. Two plots $25 \mathrm{~m} \mathrm{x} 25 \mathrm{~m}$ each were selected for sampling in each of the five distinct physiognomies. Five replicates soil samples were randomly collected at $0-15 \mathrm{~cm}$ soil depth in dry and rainy seasons in each site and they were subjected to seedlings emergence for six months to determine the density and species composition (natives or aliens and percentage contribution) of the seed bank. The results of the seedling emergence revealed that the seed bank was dominated by herbaceous stems and also the proportion of aliens to natives was low. Analysis of variance revealed that there was no significant difference $(\mathrm{P}>0.05)$ in the density of both the aliens and native species in sites A, B and C indicating similarities in the seed bank density of the aliens and natives in the three sites while in sites $\mathrm{D}$ and $\mathrm{E}$, there was a significant difference $(\mathrm{P}<0.05)$ indicating dissimilarity in the seed bank density of the aliens and natives in the two sites.
\end{abstract}

(C) 2021 International Formulae Group. All rights reserved.

Keywords: Plant Ecology, Forest, Seedling Emergence, Seed Bank, Alien Species, Conservation.

\section{INTRODUCTION}

Invasive alien species are regarded as one of the greatest threats to global biodiversity (Sala et al., 2000) as they disrupt the composition and functioning of local ecosystems (Chapin et al., 2000; Richadson et al., 2000; Levine et al., 2003) and pose serious economic and health problems (Davis, 2003). They have gained considerable notoriety as being major threats to native species and ecosystems (Kunwar, 2003).

The introduction of alien species could lead to changes in community structure and the loss of native species, ecosystem functions and services (Reaser et al., 2007; Spotswood et al., 2012; Rojas-Sandoval et al., 2016). Human activities are known drivers for the spread and establishment of invasive species (Reaser et al., 2007; Kuffer et al., 2010; Richardson \& Pysek, 
2012). The distribution and abundance of invasive species can also be strongly influenced by vectors that facilitate their dispersal (Mortenson et al., 2009; Von der Lippe \& Kowarik, 2012). Besides being an indirect measure of economic development, the presence of paved roadways can play a crucial role by serving as corridors for the spread of invasive species as well as by providing particularly propitious habitats (open and disturbed) for their establishment (Pauchard \& Alaback, 2004; Sharma \& Raghubanshi, 2009; Jolly et al., 2011; Vakhlamova et al., 2016).

Introducing plant species into a new environment can have many unanticipated ecological effects. Whether deliberately or accidentally introduced as ornamentals or economic plants, new species can have negative impacts on ecosystem quality and biodiversity by suppressing the growth of indigenous species and facilitating habitat alteration.

Recently there is increasing interest in the composition of forest seed banks but still forest reserves seed banks have received relatively little attention in comparison with those of arable fields and grasslands (Bossuyt and Hermy, 2002). However, the crucial and controversial question of whether soil seed banks play an important role in regeneration of tropical forest has been difficult to resolve because of regeneration from seeds that have recently dispersed into the site. Nonetheless, seeds on germinating, form part of a future generation (Olatunji et al., 2015).

The seed bank of a habitat can be very different from the apparent vegetation (Bossuyt and Harmony, 2008; Koncz et al., 2011) because in more persistent habitats like forests there are more species producing larger seeds in less numbers and shorter viability (Matus et al., 2005; Bossuyt and Harmony, 2008). Most of the seeds in the seed bank come from the nearby plants, while the remaining seeds are contributed by plant communities, long distance away from the parent plants (Solomon, 2011). The persistence of viable seed in the soil seed bank depends on a wide range of interacting factors, such as production practices and environmental conditions (Neve et al., 2011; Korres et al., 2018).

The study of seeds banks also provides information about the past management practices and their impact on the current and future vegetation (Valko et al., 2011). The seed bank also provides information about the former and apparent levels of degradation (Hong et al., 2012) and has a decisive role in the temporal dispersal of species contributing to the conservation of the genetic variability of plant populations (Hong et al., 2012). It may also have a role in habitat restoration which topic is in the mainstream of seed bank studies. Most results suggested that the seed bank has a limited importance in habitation restoration processes and successful restoration needs propagule input (Blomqvist et al., 2003; Rosef, 2008; Stroh et al., 2012). Other studies claim that seed banks may have role in the habitat restoring but spontaneous recovery requires long time (Plassmann et al., 2009; Wang et al., 2010).

Forest reserves are protected areas of importance for wildlife, flora, fauna or features of geological or other special interest which is reserved and managed for conservation and to provide special opportunities for study or research. The forest reserve in Nigeria is estimated to cover about 10 million hectares, which accounts for more than $10 \%$ of land area of approximately 962 million hectares, 923768 $\mathrm{km}^{2}$ with a population of about 170,790 in 2006 and is experiencing a drastic decline at a rate of $3.5 \%$ annually due to over-exploitation of the forest ecosystem (Obioha, 2009). The degradation of forest ecosystem is usually accompanied by species extinction, reduction in biodiversity and decrease in primary productivity (Gbetoho et al., 2017). These forest reserves are owned by the State Government and managed by the State Forestry Departments.

This study determines the proportion of the seedling emergence of the aliens to the natives and also their percentage contributions to the seed bank in the five distinct vegetation physiognomies in Akure Forest Reserve, Ondo State, Nigeria. 


\section{MATERIALS AND METHODS}

\section{The study area}

The study sites are located in the Akure Forest Reserve, Aponmu near Akure in Ondo State within Southwestern Nigeria. Akure Forest Reserve has an area of $69.93 \mathrm{~km}^{2}$ and lies approximately on latitude $7^{0} 18^{\prime} \mathrm{N}$ and longitude $5^{\circ} 02^{\prime} \mathrm{E}$ (Jones, 1948) at an altitude of $250 \mathrm{~m}$ above sea level (Ola Adams and Hall, 1987).

The Akure Forest Reserve was originally a natural forest unmodified by exploitation or any other form of interference for several years until when a part of it was exploited for timber thereby reducing it to the status of a secondary forest (Whitmore, 1975).

The climate is humid tropical (Thornthwaite, 1948) with seasonal variations in rainfall, temperature and humidity. The mean annual rainfall is about $1500 \mathrm{~mm}$ (Thornthwaite, 1948) with double maxima in the months of July and September and a short relatively dry period in August. December through February constitutes the major dry season while January and February are the driest months. Temperature ranges from 20.6 ${ }^{0} \mathrm{C}$ to $33.5^{\circ} \mathrm{C}$; the monthly mean temperature is about $27^{\circ} \mathrm{C}$.

The relative humidity at 15 hours Greenwich Mean Time (G.M.T.) is highest in July and September and lowest in February at about 81 and 44 percent respectively (Fagbenro et al., 1976). The natural vegetation of the area was classified by Keay (1953) as Dry Lowland rainforest (Anon, 1998). The Permanent sample plot (PSP) and the inviolate portions of the forest reserve are still relatively undisturbed typical rainforest whereas areas outside the conservation plots showed traces of relative exploitation. This is evidenced by the presence of artefacts such as pottery and charcoal pieces as well as the presence of oil palm trees in several places. Jones (1948) also opined that the high density of emergents would seem to indicate that the area had been part of a farming mosaic at some not distant periods probably before the constitution of the forest reserve early in the $20^{\text {th }}$ century. However, the species diversity of the forest attests to its highly rich floristic composition.
The emergents and sub-emergents of the multi-strata high forest contain economic trees like Sterculia rhinopetala, Diospyros mespiliformis, Mansonia altissima, Celtis zenkeri, Antiaris toxicara, Terminalia ivorensis, Terminalia superba, Lovoa trichiliodes, Triplochiton scleroxylon, Milicia excelsa, and Nesogordonia papaverifera. In the shrub layer, economic and lesser known species include Myrianthus arboreus, Mallotus oppositifolius, Annickia chloranta, Dennetia tripetala, and Tabernaemontana pachysiphon. Almost all big species and medium sized trees were entangled with creepers and epiphytes while the forest floor had various types of herbs and litter. The forest cover of the vegetation has been un-modified for several decades (OlaAdams and Hall, 1987).

\section{Selection of study plots}

The Akure Forest Reserve was demarcated into five (5) distinct study sites and physiognomies namely; A, B, C, D and E; representing all the physiognomies present in the Akure forest reserve. Site A is a Natural forest, $\mathrm{B}$ is a Teak plantation, $\mathrm{C}$ is a Taungya system, D is Taungya + Teak + Gmelina while site E is Teak + Gmelina + Pinus Plantation. Two study plots each measuring $25 \mathrm{~m} \times 25 \mathrm{~m}$ from each of the five physiognomies were selected for each of the dry and rainy seasons.

\section{Assessment of the soil seed bank for alien and native plant species}

In each of the study plots, five (5) replicate soil samples were randomly collected in each of the dry and rainy seasons to a depth of $0-15 \mathrm{~cm}$ using a metal soil auger at specific intervals. The soil samples were put in polythene bags and labeled after collection and transported to the laboratory at the Department of Botany, Obafemi Awolowo University, IleIfe, Osun State, where the samples were spread on benches for air drying and occasionally turned for proper drying.

\section{Seedling emergence test}

The soil samples collected and air dried were spread in porous shallow plastic plates (to allow excess water drain out) in the screen 
house where they were watered daily and monitored for seedling emergence tests. When the seedlings emerged from the soil samples in the plates they were identified, counted and removed. Germinated seeds were observed and counted daily up to six months to confirm no further seed germination. Seedlings whose identifications were doubted at the early stage were given codes and transplanted into bigger plots for further growth and proper identification. The soil samples were stirred and turned at intervals to enhance germination of the seeds. The roots of removed plants were rinsed because the soil attached to the roots might contain seeds which might be discarded.
Seedling emergence studies were done with a view to determining the density and species composition of the seed banks of the study plots. Identified seedlings were classified into alien and native species. The percentage contribution of each species to the soil seed bank flora was determined in each of the dry and rainy seasons

\section{Statistical analysis}

Analysis of variance was used to compare seedling emergence of the aliens and natives in all the sites and the total soil seed bank.

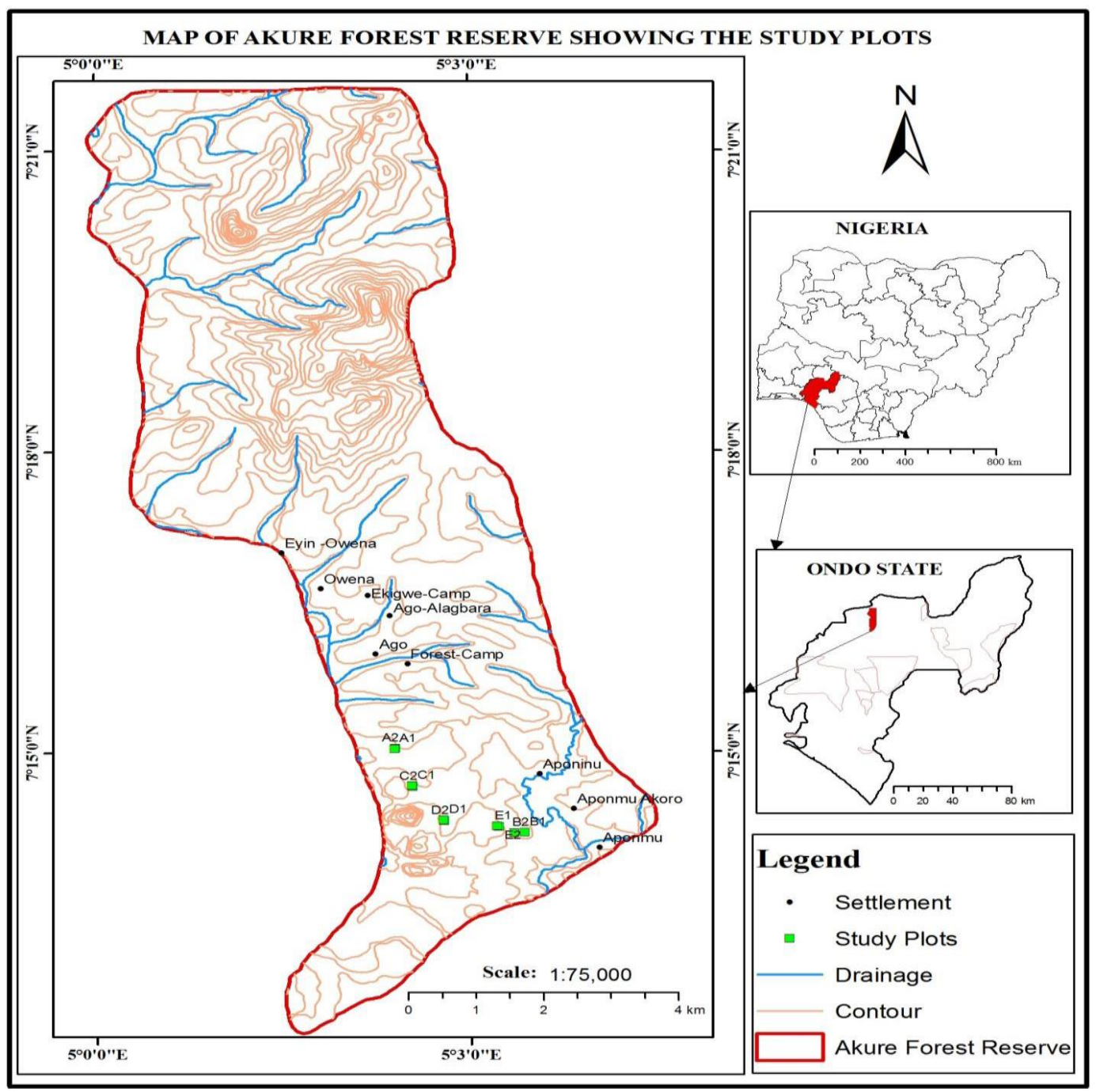

Figure 1: Map of Akure Forest Reserve Showing the Study Plots. 


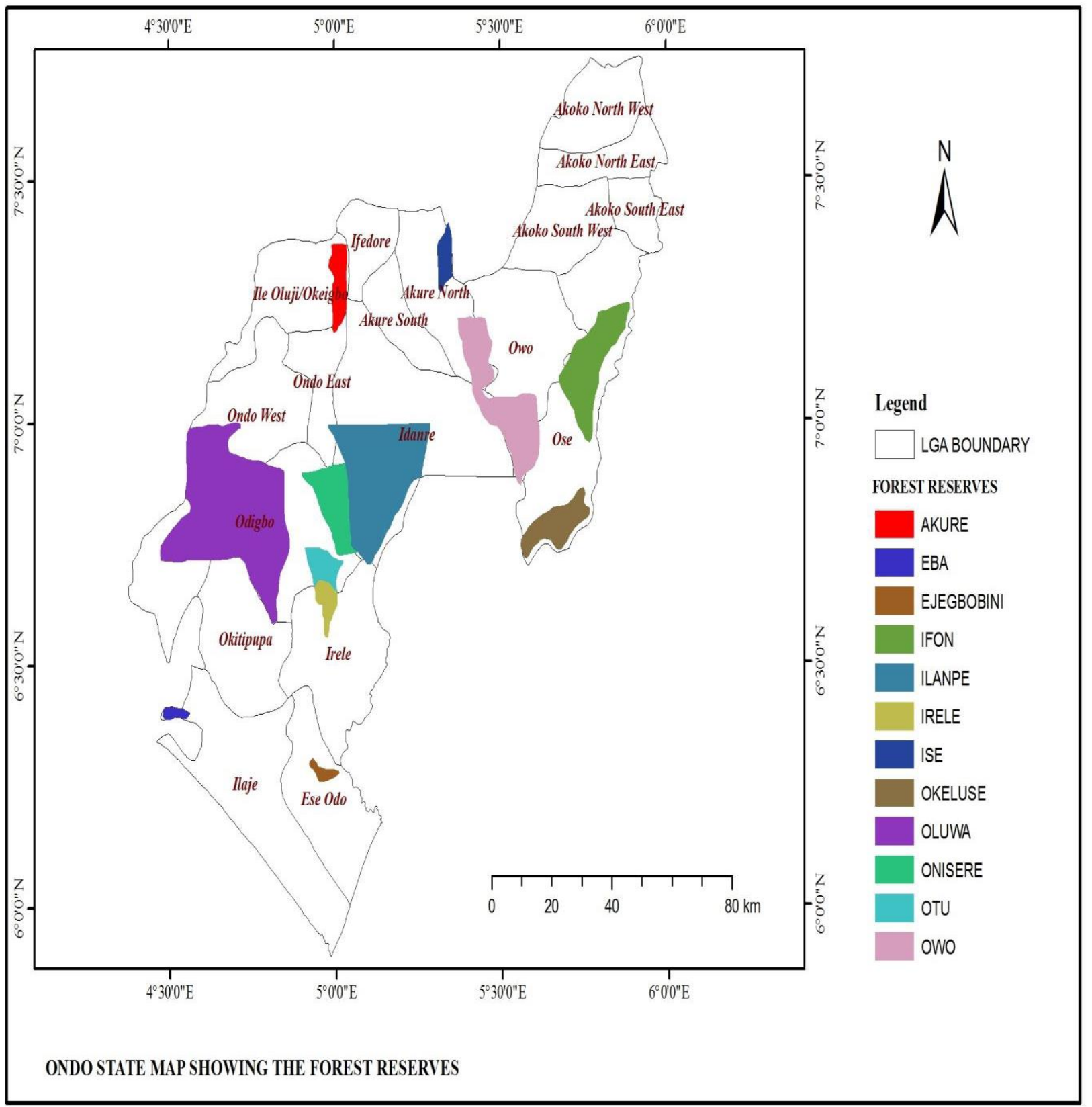

Figure 2: Ondo State Map Showing the Forest Reserves. 


\section{RESULTS}

Seedling emergence of aliens and indigenous species in the five study sites in dry and rainy seasons soil collected at $\mathbf{0 - 1 5} \mathrm{cm}$ depth Site A (natural forest)

A mean total of 33 seedlings or $297 \pm 27$ seeds $/ \mathrm{m}^{2}$ emerged at the natural forest (Site A) from the $0-15 \mathrm{~cm}$ soil depth. Seven species emerged consisting of two woody species with a density of $216 \pm 27$ seeds $/ \mathrm{m}^{2}$ and five were herbaceous plants with a total density of 9 seedlings or 81 seeds $/ \mathrm{m}^{2}$ (Table 1 ). The only alien species that contributed to the seed bank of site A during the dry season was Chromolaena odorata (an herbaceous plant) with a seed density of $18 \mathrm{seeds} / \mathrm{m}^{2}$ or $6.06 \%$ of the total seed bank, other plants were native.

During the rainy season seedling emergence site A mean total of 15 seedlings or 135 seeds $/ \mathrm{m}^{2}$ at $0-15 \mathrm{~cm}$ depth consisting of one woody species out of a total of six species present in the Site (Table 1) while the other five species were herbaceous. Two alien species that were found were Chromolaena odorata (an alien herbaceous plant) and Ageratum conyzoides, Chromolaena odorata made the highest contribution to the seed bank of Site A during the rainy season with a total of 36 seeds $/ \mathrm{m}^{2}$ or $26.65 \%$ of the total density of the seed bank. Ageratum conyzoides was the second highest with a total of three (3) seedlings $\left(27 \mathrm{seeds} / \mathrm{m}^{2}\right)$ or $20 \%$ of the total density of the seed bank. Alien species made a contribution of $46.67 \%$ to the seed bank of the site during the rainy season while native species made a contribution of $53.33 \%$.

\section{Site B (teak plantation)}

Sixty seedlings or $540 \pm 99$ seeds $/ \mathrm{m}^{2}$ emerged from the $0-15 \mathrm{~cm}$ depth in the teak plantation (Table 2). A total of seven (7) species were found in the seed bank; all herbaceous. The only alien species found in the seed bank was Chromoleana odorata with a seed density of 20 seedlings or $180 \pm 90$ seeds $/ \mathrm{m}^{2}$. It contributed $33.33 \%$ to the total seed bank of the site. Other species found in the site were all natives.

At the same depth during the rainy season sampling, site B had a mean total of 31 seedlings or 279 seeds $/ \mathrm{m}^{2}$ (Table 2). Seedling emergence was $100 \%$ herbaceous consisting of only four species. Chromolaena odorata (the only alien plant present in the site) made the second highest contribution of $72 \mathrm{seeds} / \mathrm{m}^{2}$ or $25.8 \%$ of the total seed bank in the site.

Other species found in the site were natives and they contributed a total amount of $74.2 \%$ to the seed bank of the site.

\section{Site C (Taungya system)}

In the dry season sampling, at $0-15 \mathrm{~cm}$ depth site C (Taungya system) had a mean total of 351 seedlings or $3159 \pm 391$ seeds $/ \mathrm{m}^{2}$ (Table 3). Seven (7) species emerged in the seed bank of the site and all were herbaceous consisting of five indigenous species and two alien species (Ageratum conyzoides and Chromolaena odorata). Ageratum conyzoides had 9 seeds $/ \mathrm{m}^{2}$ or $0.28 \%$ of the total seed bank while Chromolaena odorata had 162 \pm 36 seeds $/ \mathrm{m}^{2}$ or $5.12 \%$ of the total seed bank.Pepperomia pelucida (a native species) dominated the seed bank with a total of 295 seedlings $\left(2655+1395 \mathrm{seeds} / \mathrm{m}^{2}\right)$ or $84.04 \%$ of the total density of the seed bank. Aliens contributed a total percentage of $5.7 \%$ while native species contributed $94.3 \%$.

During the rainy season seedling emergence, at $0-15 \mathrm{~cm}$ depth, Site $\mathrm{C}$ had a mean total of 243 seedlings or $2187 \pm 630$ seeds $/ \mathrm{m}^{2}$ (Table 3) was recorded in the site. Herbs dominated the seed bank of site $\mathrm{C}$ with a total of 238 seedlings or 2142 seeds $/ \mathrm{m}^{2}$. Herb seedlings contributed $97.5 \%$ to the total seed density of the seed bank.

A total of ten (10) species were found in site $\mathrm{C}$ consisting of eight native species and two alien species. The aliens present in the seed bank were Chromolaena odorata $(351 \pm 81$ seeds $/ \mathrm{m}^{2}$ or $\left.16.05 \%\right)$ of the total seed bank and Ageratum conyzoides $\left(171 \pm 9\right.$ seeds $/ \mathrm{m}^{2}$ or 
$7.81 \%$ ) of the total seed bank). Aliens contributed a total percentage of $23.86 \%$ to the seed bank while native species contributed $76.14 \%$.

\section{Site D (Taungya+ Teak + Gmelina)}

In the dry season sampling, site D (Taungya+Teak+Gmelina) at $0-15 \mathrm{~cm}$ depth had a mean total of 568 seedlings or $5112 \pm 1836$ seeds $/ \mathrm{m}^{2}$; the highest number of species during the dry season seedling emergence in all the study sites (Table 4). Fourteen (14) species emerged out of which two (2) were aliens. Also two (2) woody species emerged from the seed bank while others were herbaceous, Pepperomia pelucida (a herbaceous plant) made the highest contribution of $73.94 \%$ to the total seed bank of the site. The aliens species present in the site during the dry season seedling emergence were Carica papaya $\left(27 \pm 9 \quad\right.$ seeds $\left./ \mathrm{m}^{2}\right)$ and Chromolaena odorata (243 seeds $\left./ \mathrm{m}^{2}\right)$ which contributed $0.52 \%$ and $4.75 \%$ to the total seed bank respectively. Alien species contributed a total of $5.29 \%$ while native species contributed a total of $94.71 \%$.

During the rainy season sampling, at 0 $15 \mathrm{~cm}$ depth, site $\mathrm{D}$ had a mean total of 430 seedlings or $3870 \pm 197$ seeds $/ \mathrm{m}^{2}$. Eleven (11) species emerged in the site consisting of ten native species and one alien species (Table 4.4). Woody species seedlings accounted for $3.71 \%$ of the seed density of the seed bank while herb seedlings accounted for $96.29 \%$ of the total seed density of the seed bank.

Pepperomia pelucida (a herbaceous plant) made the highest contribution to the seed bank with a total of 325 seedlings (2925 \pm 531 seeds $/ \mathrm{m}^{2}$ ) or $75.58 \%$ of the total density of the seed bank. Lantana camara was the only alien plant found in the seed bank of the site D $(63 \pm 9$ seeds $/ \mathrm{m}^{2}$ or $1.63 \%$ of the seed bank). Indigenous species contributed a total of $98,37 \%$ to the seed bank.
Site E (Teak+ Gmelina + Pinus Plantation)

In the dry season sampling, Site E (Teak+Gmelina+Pinus Plantation) had a mean total of 87 seedlings or $783 \pm 225$ seeds $/ \mathrm{m}^{2}$ at 0 $15 \mathrm{~cm}$ depth (Table 5). All seedlings found in the seed bank were $100 \%$ herbaceous. Ten species were present in the seed bank and were all indigenous. No alien plants species was found in the seed bank of this site during the season.

During the rainy season sampling, Site E had a mean total of $855 \pm 225$ seeds $/ \mathrm{m}^{2}$ or 95 seedlings. Nine (9) species emerged from the seed bank of this site during the rainy season consisting of three alien species and six indigenous species. The aliens found in the site during the rainy season seedling emergence were Carica papaya, Chromolaena odorata and Ageratum conyzoides. Aliens contributed $19.9 \%$ to the total seed bank while indigenous species contributed $80.1 \%$.

\section{Seedling emergenence of aliens and native species in the seed bank of the five study sites in Akure Forest Reserve}

In all the five study sites, only two alien woody species emerged from the seed bank. They were Lantana camara and Carica papaya. Lantana camara emerged from site D during the rainy season soil collection while Carica papaya emerged in site $\mathrm{D}$ during the rainy season soil collection and also in site $\mathrm{E}$ during the rainy season soil collection. The other alien species that emerged in all the study sites were herbaceous (Chromolaena odorata and Ageratum conyzoides). All other seedlings that emerged were all natives. There was no significant difference $(\mathrm{P}>0.05)$ in seed bank densities of both the alien and indigenous species in plots $\mathrm{A}, \mathrm{B}$ and $\mathrm{C}$ while in plots $\mathrm{D}$ and $\mathrm{E}$, there was a significant difference $(\mathrm{P}<0.05)$ when Analysis of variance was applied. 
Table 1: mean density (seed $/ \mathrm{m}^{2}$ ) and percentage contribution of each species in the seed bank of site A (natural forest) in both dry and rainy season collections at $0-15 \mathrm{~cm}$.

\begin{tabular}{|c|c|c|c|c|c|c|}
\hline \multirow[b]{2}{*}{ Name of Species } & \multirow[b]{2}{*}{ HABIT } & \multirow[b]{2}{*}{ STATUS } & \multicolumn{2}{|l|}{ DRY } & \multicolumn{2}{|l|}{ RAINY } \\
\hline & & & $\begin{array}{l}\text { SEASON } \\
\text { SEEDS/m² }\end{array}$ & $\begin{array}{l}\% \\
\text { Seedbank }\end{array}$ & $\begin{array}{l}\text { SEASON } \\
\text { SEEDS/m² }\end{array}$ & $\begin{array}{l}\% \\
\text { Seedbank }\end{array}$ \\
\hline Ageratum conyzoides & $\mathrm{H}$ & $\mathrm{A}$ & & & 27 & 20 \\
\hline Brilliantasia nitens & $\mathrm{H}$ & I & & & 9 & 6.66 \\
\hline Cissus spp & $\mathrm{H}$ & I & 9 & 3.03 & & \\
\hline Chromolaena odorata & $\mathrm{H}$ & A & 18 & 6.06 & 36 & 26.66 \\
\hline Commelina benghalensis & $\mathrm{H}$ & $\mathrm{I}$ & 18 & 6.06 & & \\
\hline Cnestis ferruginea & $\mathrm{W}$ & I & & & 18 & 13.33 \\
\hline Cyathula spp. & $\mathrm{H}$ & I & 27 & 9.09 & & \\
\hline Fleurya ovalifolia & $\mathrm{H}$ & $\mathrm{I}$ & 9 & 3.03 & & \\
\hline Pepperomia pelucida & $\mathrm{H}$ & $\mathrm{I}$ & & & 9 & 6.66 \\
\hline Solanum erianthum & $\mathrm{W}$ & I & $45 \pm 27$ & 15.15 & 36 & 26.66 \\
\hline Trema orientalis & $\mathrm{W}$ & $\mathrm{I}$ & 171 & 57.57 & & \\
\hline Total & & & $297 \pm 27$ & $100 \%$ & 135 & $100 \%$ \\
\hline
\end{tabular}

W: WOODY ; H: HERBACEOUS; I: INDIGENOUS; A: ALIEN

Table 2: mean density (seed $/ \mathrm{m}^{2}$ ) and percentage contribution of each species in the seed bank of site $\mathrm{B}$ (Teak plantation) in both dry and rainy season collections at $0-15 \mathrm{~cm}$.

\begin{tabular}{|c|c|c|c|c|c|c|}
\hline Name of Species & HABIT & STATUS & $\begin{array}{l}\text { DRY SEASON } \\
\text { SEEDS/m² }\end{array}$ & $\begin{array}{l}\% \text { Seed } \\
\text { bank }\end{array}$ & $\begin{array}{l}\text { RAINY } \\
\text { SEASON } \\
\text { SEEDS/m² }\end{array}$ & $\begin{array}{l}\% \text { Seed } \\
\text { bank }\end{array}$ \\
\hline Chromolaena odorata & $\mathrm{H}$ & $\mathrm{A}$ & $180 \pm 90$ & 33.33 & 72 & 2580 \\
\hline Cythula spp. & $\mathrm{H}$ & I & 27 & 5 & & \\
\hline Larpotea aestuans & $\mathrm{H}$ & $\mathrm{I}$ & 207 & 38.33 & 126 & 45.16 \\
\hline Larpotea ovalifolia & $\mathrm{H}$ & I & 9 & 1.66 & & \\
\hline Pepperomia pelucida & $\mathrm{H}$ & $\mathrm{I}$ & $63 \pm 9$ & 11.66 & 45 & 16.12 \\
\hline Spigelia altimea & $\mathrm{H}$ & $\mathrm{I}$ & 9 & 1.66 & & \\
\hline Talinum triangulare & $\mathrm{H}$ & $\mathrm{I}$ & 45 & 8.33 & 36 & 12.90 \\
\hline Total & & & $540 \pm 99$ & $100 \%$ & 279 & $100 \%$ \\
\hline
\end{tabular}


Table 3: mean density $\left(\right.$ seeds $/ \mathrm{m}^{2}$ ) and percentage contribution of each species in the seed bank of site $\mathrm{C}$ (Taungya system) in both of dry and rainy season collections at $0-15 \mathrm{~cm}$

\begin{tabular}{|c|c|c|c|c|c|c|c|}
\hline Name of Species & HABIT & STATUS & $\begin{array}{l}\text { DRY SEASON } \\
\text { SEEDS } / \mathrm{m}^{2}\end{array}$ & $\begin{array}{l}\% \text { Seed } \\
\text { bank }\end{array}$ & $\begin{array}{l}\text { RAINY } \\
\text { SEASON } \\
\text { SEEDS/m² }\end{array}$ & $\begin{array}{l}\% \\
\text { bank }\end{array}$ & Seed \\
\hline Ageratum conyzoides & $\mathrm{H}$ & $\mathrm{A}$ & 9 & 0.28 & $171 \pm 9$ & 7.81 & \\
\hline Chromolaena odorata & $\mathrm{H}$ & $\mathrm{A}$ & $162 \pm 36$ & 5.12 & $351 \pm 81$ & 16.04 & \\
\hline Ipoemea involucrata & $\mathrm{H}$ & I & & & 54 & 2.46 & \\
\hline Larpotea aestuans & $\mathrm{H}$ & $\mathrm{I}$ & $189 \pm 171$ & 5.98 & $270 \pm 54$ & 12.34 & \\
\hline Larpotea ovalifolia & $\mathrm{H}$ & I & $81 \pm 45$ & 2.56 & & & \\
\hline Peperomia pellucida & $\mathrm{H}$ & I & $2655 \pm 2475$ & 84.04 & $936 \pm 486$ & 42.79 & \\
\hline Piper guineensis & $\mathrm{H}$ & $\mathrm{I}$ & & & 36 & 1.64 & \\
\hline Poulzolzia guineensis & $\mathrm{H}$ & I & 18 & 0.56 & & & \\
\hline Euphorbia spp. & $\mathrm{H}$ & I & & & 18 & 0.82 & \\
\hline Solanum `erianthum & $\mathrm{W}$ & I & & & 45 & 2.05 & \\
\hline Talinum triangulare & $\mathrm{H}$ & $\mathrm{I}$ & 45 & 1.42 & & & \\
\hline Vigna gracilis & $\mathrm{H}$ & I & & & 54 & 2.46 & \\
\hline CODE A & & & & & 252 & 11.52 & \\
\hline Total & & & $3159 \pm 2727$ & $100 \%$ & $2187 \pm 630$ & $100 \%$ & \\
\hline
\end{tabular}

W: WOODY ; H: HERBACEOUS; I: INDIGENOUS; A: ALIEN

Table 4: mean density $\left(\right.$ seeds $\left./ \mathrm{m}^{2}\right)$ and percentage contribution of each species in the seed bank of site $\mathrm{D}$ (Taungya + Gmelina + Teak) in both of dry and rainy season collection at 0-15 cm.

\begin{tabular}{|c|c|c|c|c|c|c|}
\hline Name of species & HABIT & STATUS & $\begin{array}{l}\text { DRY } \\
\text { SEASON } \\
\text { SEED/m² }\end{array}$ & $\begin{array}{l}\% \text { Seed } \\
\text { bank }\end{array}$ & $\begin{array}{l}\text { RAINY } \\
\text { SEASON } \\
\text { SEEDS/M2 }\end{array}$ & $\begin{array}{l}\% \text { Seed } \\
\text { bank }\end{array}$ \\
\hline Ageratum conyzoides & $\mathrm{H}$ & I & & & $63 \pm 9$ & 1.62 \\
\hline Amaranthus spp. & $\mathrm{H}$ & I & 9 & 0.17 & & \\
\hline Andropogon spp. & $\mathrm{H}$ & I & 9 & 0.17 & 18 & 0.46 \\
\hline Chromolaena odorata & $\mathrm{H}$ & A & $243 \pm 27$ & 4.75 & & \\
\hline Cythula spp. & $\mathrm{H}$ & $\mathrm{I}$ & $36 \pm 18$ & 0.70 & & \\
\hline Carica papaya & $\mathrm{W}$ & $\mathrm{A}$ & $27 \pm 9$ & 0.52 & & \\
\hline Oplisimenus baumanii & $\mathrm{H}$ & I & 18 & 0.35 & & \\
\hline Larpotea aestuans & $\mathrm{H}$ & I & $99 \pm 81$ & 1.93 & $117 \pm 63$ & $3-02$ \\
\hline Larpotea ovalifolia & $\mathrm{H}$ & I & 126 & 2.46 & & \\
\hline Lantana camara & $\mathrm{W}$ & $\mathrm{A}$ & & & $63 \pm 9$ & 1.62 \\
\hline Phyllanthus amarus & $\mathrm{H}$ & I & & & 9 & 0.23 \\
\hline Poulzolzia guineensis & $\mathrm{H}$ & I & $351 \pm 333$ & 6.86 & & \\
\hline Peperomia pellucida & $\mathrm{H}$ & I & $3780 \pm 1278$ & 73.94 & $2925 \pm 531$ & 75.58 \\
\hline Solanum erianthum & $\mathrm{W}$ & I & 45 & 0.88 & 72 & 1.86 \\
\hline Spigelia altimea & $\mathrm{H}$ & I & $63 \pm 9$ & 1.23 & & \\
\hline Talinum triangulare & $\mathrm{H}$ & $\mathrm{I}$ & $297 \pm 81$ & 5.80 & $513 \pm 63$ & 13.25 \\
\hline Rauvolvia vomitoria & $\mathrm{W}$ & $\mathrm{I}$ & & & 9 & 0.23 \\
\hline Vigna gracilis & $\mathrm{H}$ & I & 9 & 0.17 & & \\
\hline$C O D E B$ & & & & & 54 & 1.39 \\
\hline$C O D E C$ & & & & & 27 & 0.69 \\
\hline Total & & & $5112 \pm 1836$ & $100 \%$ & $3870 \pm 197$ & $100 \%$ \\
\hline
\end{tabular}

W: WOODY ; H: HERBACEOUS; I: INDIGENOUS; A: ALIEN 
Table 5: mean density $\left(\right.$ seeds $/ \mathrm{m}^{2}$ ) and percentage contribution of each species in the seed bank of site $\mathrm{E}$ (Pinus + Teak+ Gmelina) in both of dry and rainy season collections at 0-15 cm.

\begin{tabular}{|c|c|c|c|c|c|c|}
\hline \multirow[b]{2}{*}{ Name of species } & \multirow[b]{2}{*}{ HABIT } & \multirow[b]{2}{*}{ STATUS } & \multicolumn{2}{|l|}{ DRY } & \multicolumn{2}{|l|}{ RAINY } \\
\hline & & & $\begin{array}{l}\text { SEASON } \\
\text { SEED/m }\end{array}$ & $\begin{array}{l}\% \text { bank } \\
\text { Seed }\end{array}$ & $\begin{array}{l}\text { SEASON } \\
\text { SEEDS/M }^{2}\end{array}$ & $\begin{array}{l}\% \text { Seed } \\
\text { bank }\end{array}$ \\
\hline Ageratum conyzoides & $\mathrm{W}$ & A & & & $63 \pm 27$ & 7.36 \\
\hline Amaranthus spp. & $\mathrm{H}$ & I & & & 36 & 4.21 \\
\hline Carica papaya & $\mathrm{W}$ & A & & & 18 & 2.10 \\
\hline Corchorus aestuans & $\mathrm{H}$ & I & 9 & 1.14 & & \\
\hline Chromolaena odorata & $\mathrm{H}$ & A & & & 90 & 10.52 \\
\hline Cyathula spp. & $\mathrm{H}$ & $\mathrm{I}$ & 36 & 4.59 & & \\
\hline Cissus spp. & $\mathrm{H}$ & I & & & 9 & 1.05 \\
\hline Euphorbia heterophylla & $\mathrm{H}$ & I & 72 & 9.19 & & \\
\hline Euphorbia migrans & $\mathrm{H}$ & I & 18 & 2.29 & & \\
\hline Euphorbia graminii & $\mathrm{H}$ & $\mathrm{I}$ & 9 & 1.14 & & \\
\hline Eluise indica & $\mathrm{H}$ & I & 36 & 4.59 & & \\
\hline Peperomia pellucida & $\mathrm{H}$ & I & $126 \pm 90$ & 1609 & 243 & 28.42 \\
\hline Piper guineesis & $\mathrm{H}$ & I & & & 9 & 1.05 \\
\hline Poulzolzia guineensis & $\mathrm{H}$ & I & & & 9 & 1.05 \\
\hline Talinum triangulare & $\mathrm{H}$ & I & $459 \pm 135$ & 58.62 & $378 \pm 198$ & 44.21 \\
\hline Spigelia altimea & $\mathrm{H}$ & $\mathrm{I}$ & 9 & 1.14 & & \\
\hline Vigna gracilis & $\mathrm{H}$ & $\mathrm{I}$ & 9 & 1.14 & & \\
\hline Total & & & $783 \pm 225$ & $100 \%$ & $855 \pm 225$ & $100 \%$ \\
\hline
\end{tabular}

W: WOODY ; H: HERBACEOUS; I: INDIGENOUS; A: ALIEN

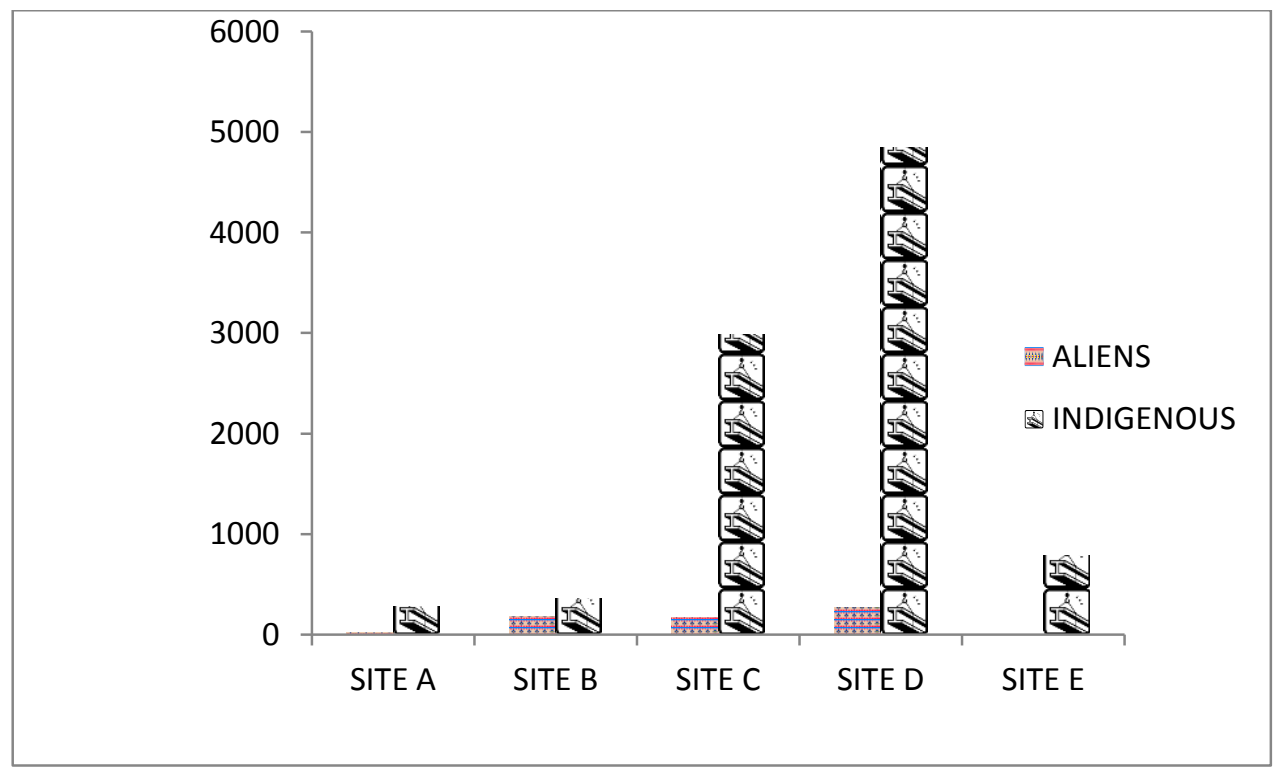

Figure 3: Seed densities of aliens and native species in the five study sites in the dry season soil collection. 


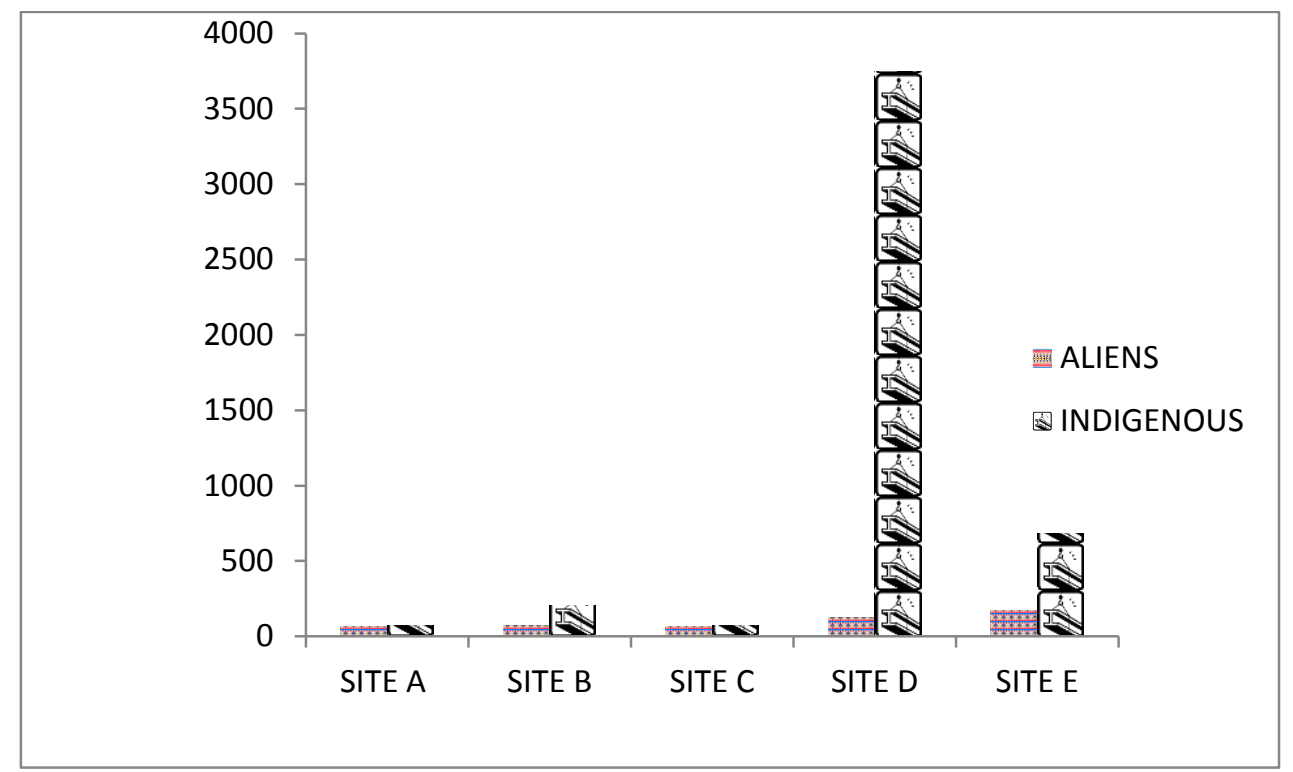

Figure 4: Seed densities of aliens and native species in the five study sites in the rainy season soil collections.

\section{DISCUSSION}

Woody species composition of the seed bank

In the present study it was observed that few woody species occurred generally in the five study sites which could be attributed to the fact that some woody species many have long germination period which may be several years after seed storage in the soil and will definitely not germinate within the short period of greenhouse experiment. Furthermore, woody species are not pioneer species that can be abundant in the seed bank. This report of few woody species in the soil seed bank is consistent with the findings of other authors such as Tinsae Assefa (2011) who worked on the seed bank composition of Besawit Forest at Abay Millenium Park Ethiopia and recorded a few woody species in the soil seed bank out of a total of 48 species in the standing vegetation. The reason for a lesser number of woody species recorded by the seedling emergence may be due to unsuitable weather conditions compared to that of the natural study area for germination in agreement with the results found by Demel Teketay (2005). Also the findings of less number of woody species in the seed bank could be due to relatively short resilence time of most woody species in corroboration of the report of Demel Teketay (2005). He also noted that as long as seeds of woody species remain on the surface, they are either attacked by predators or immediately germinate, a factor which could be responsible for the few woody species found in the seed bank as recorded in this study. Moreso, Oke et al. (2006) also observed that herbaceous species dominated the seed bank of a secondary low land forest in Nigeria.

\section{Seed bank composition of aliens and natives}

In the soil seed bank of Akure Forest Reserve five study sites, only two alien woody species seedlings (Lantana camara and Carica papaya) and two alien herbaceous species (Chromolaena odorata and Ageratum conyzoides) emerged indicating that the proportion of alien plants to natives in the seed bank is very low. This could be attributed to the fact that only five alien species though with high densities occurred in the standing vegetation, out of which only Carica papaya that have seeds that can be easily dispersed by man, insects, animals, etc. occurred in the seed bank. Moreover, others (Gmelina arborea, 
Tectona grandis, Pinus caribaea and Gliricidia sepium) that are not having seeds in the seed bank may be attributed to non-uniform dispersal of seeds in the soils and non-uniform incorporation of seeds into the top soil.

This report is in agreement with the report of earlier workers (Carlo and Aukema, 2005; Emiru Brahane et al., 2006; Hirsh et al., 2012) that seed banks are formed by seeds, either born and produced on site or carried to the site by dispersal agents and accumulated in the soil.

Furthermore, these alien woody species which were mostly deliberately planted for plantation purpose may also require long germination periods and germination requirements may not be fulfilled. Analysis of Variance was used to establish that there was however no significant difference $(\mathrm{P}>0.05)$ in seed bank densities of both the alien and native species in plots A (Natural Forest), B (Teak Plantation) and $\mathrm{C}$ (Taungya system) while in plots D (Taungya +Gmelina +Teak) and E (Teak + Pinus - Gmelina) there was a significant difference.

It was also observed in Akure forest Reserve that in the dry season soil collection at 0-15 cm depth site D had the highest alien density in the, seed bank followed by site $\mathrm{C}$ (Taungya system) and B (Teak plantation) while Site A (Natural forest) and Site E (Teak + Gmelina + Pinus) had little or no aliens in the seed bank. This could be attributed to the fact that Site D and C are disturbed sites where farming, logging and other anthropogenic activities had taken place, seed production increases after logging and consequently replenishing seed bank. This report is in agreement with (Oke et al., 2009) who reported that the dominance of the soil seed bank by the seedlings of Tithonia diversifolia in site 1 as against site 2 is a reflection of the extent of human disturbance on both sites. Site B being a Teak plantation could have open canopy which enhances the dispersal of seeds to the sites.

The lowest alien densities in the seed bank was recorded in Site A (Natural forest + Gmelina + Pinus). This could be attributed to the fact that Natural forest have close forest canopy preventing seed rain from getting to the soil. Also, Site A and E have much litter because of the presence of trees and this does not give room for easy burial of the seeds in the soil.

In the rainy season soil collection, it was generally observed that alien plants were found in all the study sites with Site D (Taungya + Teak + Gmelina) and site E (Teak + Gmelina + Pinus plantation) having the highest alien density, while other sites had how alien densities. This could be attributed to the fact that seedling emergence is usually higher during the rainy season than the dry season. This might be due to the trend of seasonal modes of seed production, dispersal and storage in the soils of the study sites. This can be further corroborated with the report of Odeleye et al. (2018) who observed that seasonal variation in seed density at sites of varying physiognomy might be related to climatically seasonal changes as seed of some species show strong seasonal shifts in density.

\section{Conclusion}

The findings of the study concluded that high seed mortality of the aliens enhanced by seed predators that feed on them have consequently reduced the reservoir of the alien seed in the soil. Furthermore, many of the alien form transient seed banks which germinate or perish before the beginning of the second germination season (Baskin et al., 2015).

The aliens in the seed bank are incapacitated to form persistent seed bank which can be helpful in predicting or understanding the invasion potentials and success of the aliens on the extant vegetation. This can be further collaborated by Gloria and Pysek (2017) who reported that the ability to form persistent seed bank of an alien species is considered an important attribute for the establishment and naturalization in new ranges. The observation of low proportion of aliens compared to natives in the seed banks as reported in the study is not indicative of serious environmental threats. Such information is crucial for developing programmes for the conservation and habitat restoration in some areas where the natural vegetation has been 
degraded as a result of some anthropogenic activities.

\section{REFERENCES}

Anonymous. 1998. Nigeria Wood and Wood Product requirements in the year 2020 . Forest Resources Study. Fed. Dept. of Forestry, Fed. Min. of Environment, Abuja, Nigeria.

Baskin CC, Baskin, JM, Yoshinaga, A. 2015. Non deep simple morphophysiological dormancy in seeds of Chelrodendron trygynun (Araliaceae) from the Montane zoon of Hawaii. Seed Science Research, 25: 203-209. DOI: 10:1017/S0960258515000112

Blomqvist MM, Bekker RM, Vos P. 2003. Restoration of ditch bank plant species richness: The potential of the soil seed bank. Applied Vegetation Science, 6:179188.

Bossuyt B, Heyn M. and Hermy V. 2002. Seed bank and vegetation composition of forest stands of varying age in central Belgium: consequences for regeneration of ancientforest vegetation. Plant Ecology. 162:33- 48

Bossuyt B, Honnay O. 2008. Can the seed bank be used for ecological communities? An overview of seed bank characteristics in European communities. Journal of Vegetation Science, 19: 875-884

Carlo, TSA, Aukema JE. 2005. Femaledirected dispersal and facilitation between a tropical mistletoe and a dioeciously host. Ecology, 201: 255-265.

Chandrashekara UM, Ramakrishnan PS. 1994. Successional Patterns and gap dynamics of humid tropical forests of the Western chats of Kerala, India: ground vegetation, Biomass, productivity and nutrient cycling. Forest Ecology and Management, 70: 23-40.

Chapin FS, Zavaleta ES, Eviner VT, Naylor RL, Vitousek PM, Reynolds HL, Hooper DU, Lavorel S, Sala OE, Hobbies SE, Mack MC, Diaz S. 2000. Consequences of changing biodiversity. Nature, 405 : 234-242.
Davis MA. 2003. Biotic globalization: Does competition from introduced species threaten biodiversity? Bio-Science, 53: 481-489.

Demel T. 2005. Seed and regeneration ecology In dry Afromontane forest of Ethiopia. Tropical Ecology, 46: 29-44.

Emiru B. Demel Teketay. Barkland, P 2006. Actual and potential contribution of enclosures to enhance biodiversity of woody species in the dry land of eastern Tigary. Drylands, 1(2): 134-147.

Gbetoho AJ, Aoudji AKN, Koura K, GourletFleury S, Kenfack D, DeCanniere C, Ganglo JC. 2017. Floristic and structural changes in secondary forests following agricultural disturbances: the case of Lama Forest reserve in Southern Benin. Int. J. Biol. Chem. Sci, 10(4): 1602-1616.

DOI: http://dx.doi.org/10.4314/ijbcs.v10i4.13

Gloria, M. and Pysek, P 2017. Early bird catches the worm: germination as a critical step in plant invasion. Biological Invasion, 19: 1055-1080.

Hirsch, BT, Veronica, RK, Pereira E. Jansen, PA 2012. Directed seed dispersal towards areas with low conspecific tree density by a scatter-hoarding rodent. Ecology Letters 1:1-7

Hong J, Liu S, Shi, G. and Zhang Y. 2012. Soil seed bank techniques for the restoring wetland vegetation diversity in Yeyawu Wetland, Beijing. Ecological Engineering, 42: 192-202.

Jolly M, Bertrand P, Gbangou R Y, White MC, Dube J. Lavoie C. 2011. Paving the way for invasive species: Road type and the spread of common ragweed (Aambrosia artemisiifola).

Environmental Management, 48: 514-522.

Jones A P D. 1948. The Natural Forest Inviolate Plot. The Nigerian Forest Service Publication, Ibadan.

Keay R W J. 1953. An outline of Nigerian Vegetation. Fed. Dept. of Forest Research.

Koncz G, Torok P, Papp M, Matus G and Tothmeresz B. 2011. Penetration of weeds into the herbaceous understorey 
and soil seed bank of a Turkey oak-sessile oak forest in Hungary. Community Ecology, 12: 227-23

Korres NE, Norsworthy JK, Young BG, Reynolds DB, Johnson WG, Conley SP, Semdal RJ, Mueller TC, Spaunhorst DJ and Gage KL. 2018. Seed bank persistence of Palmer amaranth (Amaranthus palmeri) and waterhemp (Amaranthus tuberculatus) across diverse geographical regions in the Unoited States. Weed Sci, 66: 446-456.

Kueffer C, Daehler CC, Torres-Santana CW, Lavargne C, Meyer JY, Otto R, Silva L. 2010 A global comparison of plants invasions on oceanic islands. Perspectives in plant Ecology, Evolution and Systematics, 12, 145-161

Kunwar RM. 2003. Invasive alien Plants and Eupatorium Biodiversity and Livelihood. Humalayan Journal of Sciences, Vol. Issue 2, 2003

Levine JM, Vila M, D“Antonia CM, Dukes JS, Grigulis K, Lavorel S. 2003. Mechanisms underlying the impacts of exotic plant invasions. Proceedings of the Royal Society London B, 270-781.

Matus G, Tothmeresz B, Papp M. 2005. Impact of management on vegetation dynamics and seed bank formation of inland dune grassland in Hungary. Flora, 200: 296306.

McDonald AW. 1993. The role of seed bank and sown seeds in the restoration of an English flooded meadows. Journal of Vegetation Science, 4: 395-400.

Mortensen DA, Rauschert ES, Nord AN, Jones BP. 2009. Forest roads facilitate the spread of invasive plants. Invasive plants species and Management, 2: 191-199.

Neve P, Norsworthy JK, Smith KL, Zeleya I. 2011. Modelling evolution and management of glyphosate resistance in Amaranthus palmeri. Weed Res, 51: 99112.

Obioha E. 2009. Climate Variability, Environment change and food security nexus in Nigeria. J Hum. Ecol. 26(2): 107-121.
Odeleye AA, Akinyemi DS, Olatunji OA, Komolafe ET, Oke SO. 2018. Seed bank dynamics and restoration of Ibodi monkey forest reserve, Southwestern Nigeria. Int. J. Biol. Chem. Sci., 12(6): 2830-2845.

DOI: https://dx.doi.org/10.4314/ijbcs.v12i6.28

Oke SO, Oladipo OT, Isichei AO. 2006. Seed bank dynamics and regeneration in secondary lowland rainforest in Nigeria. International Journal of Botany, 10: 3050.

Oke SO, Oladipo OT, Ndiribe CC, Akinyemi DS, Ojo OM. 2009. Soil seed bank dynamics in Tithonia diversifolia dominated fallowland at Ile Ife, Southwestern Nigeria. Int. J. Biol. Chem. Sci., 3(5): 899-911.

Ola-Adams B A. Hall J B. 1987. Soil-Plant relations in a Natural Forest Inviolate Plot at Akure, Nigeria. Journal of Tropical Ecology, 3: 57-74.

Olatunji OA, Oke SO, Isola EF, Akinyemi DS, Omodara AA. 2015. Relationship between the Standing Vegetation, Soil Properties and Soil Seed bank of an industrially degraded Vegetation of Iron Smelting Factory. Int. J. Biol. Chem. Sci., 9(2): $\quad 614-632 . \quad$ DOI: http://dx.doi.org/10.4314/ijbcs.v9i2.4

Pauchard A, Alaback PB. 2004. Influence of elevation, land use, and landscape context on patterns of alien plant invasions along roadsides in protected areas of SouthCentral Chile. Conservation Biology, 18: 238-248.

Plassmann K, Brown N, Jones ML, EdwardsJones G. 2009. Can soil seed banks contribute to the restoration of dune slacks under conservation management? Applied Vegetation Science, 12, 199-210. Reaser JK, Meyerson LA, Cronk Q, De Poorter M, Eldrege LG, Green E, Vaitu L. 2007. Ecological and socioeconomic impacts of invasive alien species in island ecosystems. Environmental Conservation, 34: 98-111.

Richardson DM, Pysek P. 2012. Naturalization of introduced plants: Ecological drivers 
of biogeography patterns. New Phytologist, 196: 383-396.

Richardson DM, Macdonald IAW. Forsyth GG. 1989. Reduction in Plant Species richness under stands of alien trees and shrubs in the fynbos biome. South African Forestry J., 149: 1-8.

Rojas-Sandoval J, Melendez-Ackerman EJ, Angeles-Alcazar D. 2016. Assessing the impacts of grass invasion on the population dynamics of a threatened Caribbean dry forest cactus. Biological Conservation, 196: 156-164.

Rosef L. 2008. Germinable soil seed banks in abandoned grasslands in central and western Norway and their significance for the restoration. Applied Vegetation Science, 11: 223-230.

Sala OE, Chapin FS, Armesto JJ, Berlow E, Bloomfield J, Dirzo R, Huber-Sanwald E, Hunneke L, Jackson RB, Kinzig A, Leemans R, Lodge DM, Mooney HA, Osterhel M, Poff NL, Sykes MT, Walker BH, Walker M, Wall DH. 2000. Biodiversity-global biodiversity scenarios for the year 2010. Science, 287: 1770-1774.

Solomon TB. 2011. Soil seed bank dynamics in relation to land management and soil types in NL Sykes MT, Walker M, Wall DH. 2000. Biodiversity-global biodiversity scenarios for the semi-arid savanna of Swaziland. African Journal of Agric. Res, B: 2494-2505.

Sharma GP, Ranghubanshi AS. 2009. Plant invasions along roads: A case study from central highlands, India. Environmental Monitoring and Assessment, 157: 191198.

Stroh PA, Hughes FMR, Spars TH, Mountford JO. 2012. The influence of time on the soil seed bank and vegetation across a landscape scale wetland restoration project. Restoration Ecology, 20: 103112.

Spotswood EN, Meyer JY, Bartolome JW. 2012. An invasive tree alters the structure of seed dispersal networks between birds and plants in French Polynesia. Journal of Biogeography, 9: 2007-2020.

Tinsay Assefa. 2011. Assessment of Soil seed bank composition in Bezawit Abay Millennium park, Bahir Dar Ethiopia. MSc thesis, Bahir Dar University (unpubl.).

Vakhlamova T, Rusterhol HP, Kanibolotskaya Y, Baur B. 2016. Effects of road tyand urbanization on the diversity and abundance of alien species in roadside verges in Western Siberia. Plant Ecology, 217: 241-252.

Van Wilgen BW, Van Wyk E. 1999. Invading alien plant in South Africa: Impacts and Solution. with International Rangeland Congress Proceedings Vol. 2.

Valko O, Torok P, Tothmeresz B, Matus G. 2011. Restoration potential in seed banks of acidic fen and dry-mesophilous meadows: Can restoration be based on local seed banks? Restoration Ecology, 19: 9-15.

Von der Lippe M, Kowarik I. 2012. Interactions between propagule pressure and seed traits shape human-medited seed dispersal along roads. Perspectives in Plant Ecology, Evolution, and Systematics, 14: 123-130.

Wang N, Jiao Jia YF, Bai WJ, Zhang ZG. 2010. Germinable soil seed banks and the restoration potential of abandoned cropland on the Chinese hilly-guided loess plateau. Environmental Management and site conditions. Journal of Vegetation Science, 18: 153-162. 